\title{
Recent advances in understanding Lynch syndrome [version
}

\section{1; peer review: 3 approved]}

\author{
Sherief Shawki, Matthew F. Kalady
}

Department of Colorectal Surgery, Digestive Disease and Surgery Institute, Cleveland Clinic, Cleveland, Ohio, USA

V1 First published: 21 Dec 2016, 5(F1000 Faculty Rev):2889
https://doi.org/10.12688/f1000research.9654.1

Latest published: 21 Dec 2016, 5(F1000 Faculty Rev):2889

https://doi.org/10.12688/f1000research.9654.1

\section{Abstract}

Colorectal cancer affects about $4.4 \%$ of the population and is a leading cause of cancer-related death in the United States. Approximately $10 \%$ to $20 \%$ of cases occur within a familial pattern, and Lynch syndrome is the most common hereditary colorectal cancer syndrome. Lynch syndrome is a hereditary predisposition to forming colorectal and extracolonic cancers, caused by a germline mutation in one of the DNA mismatch repair genes. Identifying at-risk patients and making a correct diagnosis are the keys to successful screening and interventions which will decrease formation of and death from cancers. Knowledge of the genetics and the natural history of Lynch syndrome has continued to be uncovered in recent years, leading to a better grasp on how these patients and their families should be managed. Recent developments include the approach to diagnostic testing, more precise definitions of the syndrome and risk stratification based on gene mutations, surgical decision-making, and chemoprevention.

\section{Keywords}

hereditary colorectal cancer, CRC, Lynch-Like syndrome, Tumour Lynch

\section{Open Peer Review}

Approval Status

1

2

3

version 1

21 Dec 2016

Faculty Reviews are review articles written by the prestigious Members of Faculty Opinions. The articles are commissioned and peer reviewed before publication to ensure that the final, published version is comprehensive and accessible. The reviewers who approved the final version are listed with their names and affiliations.

1. Randall Brand, University of Pittsburgh

School of Medicine, Pittsburgh, USA

2. William Grady, Fred Hutchinson Cancer Research Center, Seattle, USA

3. Marc S Williams, Geisinger Health System, Danville, USA

Any comments on the article can be found at the end of the article. 
Corresponding author: Matthew F. Kalady (kaladym@ccf.org)

Competing interests: The authors declare that they have no competing interests.

Grant information: The author(s) declared that no grants were involved in supporting this work.

Copyright: $\odot 2016$ Shawki S and Kalady MF. This is an open access article distributed under the terms of the Creative Commons Attribution License, which permits unrestricted use, distribution, and reproduction in any medium, provided the original work is properly cited.

How to cite this article: Shawki $S$ and Kalady MF. Recent advances in understanding Lynch syndrome [version 1; peer review: 3 approved] F1000Research 2016, 5(F1000 Faculty Rev):2889 https://doi.org/10.12688/f1000research.9654.1

First published: 21 Dec 2016, 5(F1000 Faculty Rev):2889 https://doi.org/10.12688/f1000research.9654.1 


\section{Introduction}

Lynch syndrome (LS) is a genetic predisposition to developing colorectal cancer (CRC) and extracolonic cancer, caused by an inherited deleterious germline pathogenic variant in one of the mismatch repair (MMR) genes or EPCAM. Responsible for approximately $3 \%$ of all CRC cases, LS is the most common hereditary CRC syndrome. Affected individuals with LS tend to develop cancers at a young age and also have higher incidences of synchronous and metachronous cancers. Multiple organ systems are at risk, including the colon, rectum, uterus, ovaries, stomach, small bowel, urinary tract, pancreas, and skin. CRC presents the highest threat, and lifetime risks are 53-69\% and 33-52\% for males and females, respectively ${ }^{1}$. The identification of Lynch kindreds followed by appropriate surveillance and management is critical to reduce the formation of cancers and mortality associated with the disease. For example, colonoscopy reduces both the incidence of and death from CRC in LS by the recognition and removal of adenomas and detection of cancer at an earlier stage ${ }^{2}$. Furthermore, because LS is dominantly inherited, risk increases for family members biologically related to the proband, and every first-degree relative of an affected individual is at $50 \%$ risk for carrying the gene mutation and therefore for also having LS. Thus, the identification of an individual with LS has ramifications for both the patient and his or her extended family.

Recognizing LS and individuals at risk can be challenging. The clinical presentation is not always "textbook", and there tend to be overlapping phenotypes with sporadic CRC and CRC within other hereditary syndromes. As the genetics of this syndrome have become further unveiled in recent years, there have been advances in our understanding of the disease and new concepts in its diagnosis and management. It is difficult to stay abreast of this rapidly changing field. This article discusses some of the recent advances over the last few years in the understanding of LS and how it has impacted clinical management. This is not intended to be a comprehensive review of LS but rather focuses on important recent developments in identification through universal testing of CRCs, risk stratification by site of mutation, improved classification of LSrelated phenotypes, implications of extended surgical resection, and new thoughts on chemoprevention. Although LS is a multi-organ disease, the scope of this article is limited mainly to colorectal manifestations and management.

\section{Genetics and diagnostic approaches}

LS is caused by a pathogenic mutation in one of four DNA MMR genes: MLH1, MSH2, MSH6, or PMS2. Additionally, there are cases of LS caused by germline deletions of the $3^{\prime}$ end of EPCAM, a gene located immediately upstream of $M S H 2$, and germline $M L H 1$ promoter hypermethylation ${ }^{3,4}$. Loss of MMR function through one of these mechanisms results in an accumulation of uncorrected mismatches that commonly occur in DNA microsatellite regions (regions of DNA with repetitive elements, including mononucleotides, dinucleotides, and trinucleotides) and eventual initiation of a tumor. Since these errors tend to occur in microsatellite areas, these tumors are called microsatellite-unstable or have high microsatellite instability (MSI). The molecular hallmark of LS cancers is this high MSI, which is present in approximately $93 \%$ of tumors 5 .
The discovery of the genetic basis of the disease has revolutionized LS diagnosis and management. However, controversy exists regarding who should be tested for LS and how it should be done. For affected individuals when tumor tissue is available, testing relies on the characteristics of Lynch-related cancers: high MSI and loss of MMR protein expression. Microsatellite stability or instability is measured by using a tumor DNA polymerase chain reaction-based test that evaluates differential DNA fragment lengths on the basis of the presence of a mutation. The presence or loss of MMR proteins within the tumor can be determined by immunohistochemistry (IHC) on paraffin-embedded tissue for one of the four previously mentioned MMR proteins. The IHC results then can guide formal germline testing for mutations in the specific gene that is not expressed ${ }^{6}$.

\section{Selecting patients for testing}

Approximately one of every 35 patients diagnosed with CRC will have LS, representing a high prevalence for a highly penetrant, dominantly inherited, potentially lethal condition ${ }^{7}$. Identifying at-risk patients remains crucial to the mission of preventing cancers and death from cancer. The most efficient and cost-effective way of screening remains debated; however, the cost analysis is evolving rapidly with the falling costs of DNA sequencing.

Traditionally, clinical criteria such as Amsterdam criteria or Bethesda guidelines have been used to identify at-risk patients and thus select those for testing. Amsterdam criteria rely on an accurate and detailed family history and have a sensitivity of less than $50 \%$. Bethesda guidelines, which incorporate pathology criteria, have a slightly higher sensitivity, approximately $70 \%^{7}$. These guidelines have been shown to be poorly implemented in clinical practice; they have a miss rate of about $28 \%$ of MSI/IHC-positive patients. Furthermore, screening only patients younger than 50 years will result in missing about half of LS cases.

In response to the lack of sensitivity, some groups have developed prediction models to help identify at-risk patients. Examples include MMR predict ${ }^{9}, \mathrm{MMRpro}^{10}$, and PREMM $^{11}$. These models function as a surrogate tool to provide quantitative estimates of the likelihood of an MMR gene mutation. Each model relies on certain clinical criteria to estimate a person's risk of having LS. The overall sensitivity and specificity are above $90 \%$ for these models ${ }^{7}$, except for the PREMM model, which has a specificity of about $67 \%{ }^{12}$. All models can be accessed and are available for use online. A risk stratification of more than $5 \%$ is highly predictive of MMR mutation and justifies pursuing genetic risk assessment. Despite the demonstrated sensitivity of these models, they still rely on clinical parameters, clinician awareness, and patient recall, which are suboptimal and limit their effectiveness. A recent development for identifying at-risk patients for LS is to screen all CRCs. In 2009, the Evaluation of Genomic Applications in Practice and Prevention Working Group recommended that all newly diagnosed CRCs undergo MSI or IHC or both ${ }^{13}$. These guidelines are endorsed by the Collaborative Group of the Americas on Inherited Colorectal Cancer ${ }^{14}$. Subsequently, the National Comprehensive Cancer Network (NCCN) further enforced the importance of universal screening but restricted it to those younger than 70 years of age 
and those older than 70 who met Bethesda guidelines ${ }^{15}$. In a recent analysis of Cleveland Clinic data, $18 \%$ of identified LS cases via the CRC universal screening program were diagnosed in patients older than 70 years (unpublished data). On the basis of this study, the authors support universal screening of all CRC, regardless of age.

Routine screening for LS by using MSI, IHC, and $M L H 1$ promoter hypermethylation in patients with CRC has been shown to be a cost-effective strategy with important clinical benefits for patients with $\mathrm{CRC}$ and their relatives ${ }^{16}$. CRC surveillance by colonoscopy for mutation carriers decreases development of cancer by more than $60 \%$ and decreases mortality from cancer by $72 \%{ }^{2}$. Therefore, the cost of routine screening should be weighed against the benefits of preventing cancers. Studies have used mathematical models to evaluate the cost-effectiveness of universal screening for LS. When at least three at-risk relatives per proband were tested for LS, the cost per life-year gained was approximately $\$ 50,000$, which is generally accepted for cost-effectiveness at the population level ${ }^{17}$. As another example, a sample of 150,000 cases of CRC was hypothetically analyzed under the assumption that $2.8 \%(4,200)$ of these cases would be LS. With the average person having four first-degree family members (each with a $50 \%$ chance of inheriting LS) and eight second-degree relatives (each with a $25 \%$ chance of inheriting LS), a total of 16,800 potential individuals with LS would be identified each year. Given that $50 \%$ of these individuals $(8,400$ people) will develop CRC, subsequent enrollment into colonoscopy surveillance programs was associated with a $60 \%$ reduction in CRC and prevented 5,040 $\mathrm{CRCs}^{18}$. However, it is estimated that only a small fraction of LS mutation carriers are diagnosed at this time and that an LS screening program would also increase this fraction substantially.

\section{Selecting a testing algorithm}

The exact testing algorithm to be used for screening of a CRC is not definitive. In its recently updated guideline on the diagnosis and management of LS, the American Gastroenterology Association strongly recommended that all CRCs be screened by using MSI or IHC for the expression of MMR proteins ${ }^{19}$. Tumors that are found to be MSI high or lack MMR protein expression should undergo further testing. If MLH1 protein is lost, the reflex testing should include analysis for a $B R A F$ mutation or methylation of the $M L H 1$ promoter region, as these findings are associated with acquired hypermethylation and do not have an inherited basis for loss of MLH1 expression as seen in LS. If $B R A F$ is wild-type or $M L H 1$ is not hypermethylated (or both occur), then it is recommended to proceed with germline mutation testing of $M L H 1$. However, up to $40 \%$ of tumors can be BRAF wild-type and still have $M L H 1$ promoter hypermethylation; therefore, in some patients, both tests may be done. If expression of the MMR proteins MSH2, MSH6, or PMS2 is lacking by IHC, then germline testing should commence for the specific gene of the protein lost ${ }^{6}$.

\section{Clinical implications of specific gene mutations}

The cumulative risk of cancer varies depending on which MMR gene is mutated. Our ability to now classify a family by the precise mutation provides health-care providers with better data to educate patients about individual cancer risks. Patients with a germline mutation in $M L H 1$ or $M S H 2$ have an overall higher cancer risk
(44-79\% and 38-78\%, respectively) compared with carriers of MSH6 and PMS2 mutations. MLH1 and MSH2 mutation carriers have the highest cumulative risk for CRCs at age 70 (50-65\% and $40-65 \%$, respectively), and the mean age of onset is $43-46$ years ${ }^{20}$. Patients with MSH6 mutations tend to develop cancers at a later age. The risk for all LS-related tumors is lower in MSH6 than MLH1 and MSH2 mutation carriers at the age of not more than 50 years (22\% versus $40 \%$ ). Owing to the higher mean age of cancer onset, by the age of 70 , the cumulative risks are similar $(73 \%$ versus $78 \%$ ). In terms of specific cancer types, male MSH6 mutation carriers have a CRC cumulative risk at age 70 similar to other genes (69\%), but the risk is only $30 \%$ for female MSH6 mutation carriers. However, female $\mathrm{MSH} 6$ mutation carriers have a higher cumulative risk of endometrial cancer ( $71 \%$ versus $27 \%$ for $M L H 1$ and $40 \%$ for $M S H 2$ mutation carriers $)^{21}$. The penetrance for $P M S 2$ mutation carriers appears to be lower than that of other MMR gene mutations. At the age of 70, carriers have cumulative risks of $25-30 \%$ for LS-related cancers, 15-20\% for CRC, and 15\% for endometrial cancer $^{22}$.

These findings have led some groups to recommend different screening and surveillance programs depending on the organ and gene mutation. However, the authors caution against increasing patient age to initiate screening, as we have identified cancers at ages younger than 30 for PMS2 and MSH6 gene mutation carriers. In fact, the NCCN has recently retracted its recommendation to start screening patients with these mutations at a later age and has the same recommendations regardless of the causative gene.

\section{Lynch-like syndrome or Tumor Lynch}

The increased use of tumor testing as an LS screening tool has led to some interesting findings. Among patients whose tumors demonstrate MSI and have loss of MMR protein expression, there is a subset of patients who do not have an identifiable germline mutation to confirm the diagnosis of LS. In the past, these patients were traditionally managed as LS because of the reluctance of health-care providers to assume that current genetic testing approaches were perfect and did not miss an underlying genetic cause. However, recent work by several groups has shown that approximately $50 \%$ of these cases can be explained by biallelic somatic mutations in the tumor $^{23-25}$. Thus, these patients do not have LS and consequently the patient and their families are not at increased risk and do not require advanced screening. Importantly, $50 \%$ of these cases of Tumor Lynch are still not defined. In this situation, a family history is even more critical to help assess likely risk. If LS cannot be eliminated from the diagnosis, these patients should be managed as if they have LS, especially if they have a suspicious family history.

\section{Adenomas in Lynch syndrome}

Although LS is traditionally considered to be a non-polyposis syndrome, recent work has defined the adenoma burden in patients with this condition. Forty-one percent of patients with LS had at least one adenoma, including $2 \%$ with six to nine adenomas and $4 \%$ with more than 10 cumulative adenomas. One patient was found to have 22 synchronous adenomas during a screening colonoscopy ${ }^{26}$. These findings raise awareness that adenomatous oligopolyposis can exist in LS. If one is suspicious that a patient could have LS, the finding of oligopolyposis should not preclude diagnostic evaluation. 


\section{The utility of extended surgical resection}

Since LS is caused by an inherited germline mutation, every cell contains that mutation and the entire colon and rectal epithelia are at risk for developing cancer. Thus, when a CRC is found, consideration must be given to extended surgical resection which is prophylactic against forming metachronous cancers in any remaining colon or rectum. For example, if a right colon cancer is diagnosed in a patient with LS, a total abdominal colectomy with an ileorectal anastomosis (rather than a right colectomy) is recommended. Multiple studies in the last few years have supported decreased metachronous CRC following extended resection. The Cleveland Clinic group reported metachronous CRC in $25 \%$ of putative Lynch patients undergoing segmental resection compared with $8 \%$ after total abdominal colectomy ${ }^{27}$. Importantly, this study also reported on the identification and removal of high-risk adenomas during surveillance in this population. As these lesions have a high likelihood of progression to cancer if not removed, they are considered surrogates for cancer. Another report demonstrated higher rates of metachronous CRC in patients with limited/segmental resections (26\%) as opposed to extended/prophylactic resection (6\%), confirming the advantages of extended resections ${ }^{28}$. A retrospective study using the Colon Cancer Family Registry aimed to evaluate the risk of developing metachronous CRC in LS patients who had either segmental or extensive (subtotal or total) resection in their index surgery. Twenty-two percent of patients undergoing segmental resection developed a metachronous $\mathrm{CRC}$, and the rates of cumulative projected risk were $16 \%, 41 \%$, and $62 \%$ at 10,20 , and 30 years, respectively ${ }^{29}$.

It is important to note that these data are all from retrospective studies and there are no prospective trials that prove extended resection improves overall survival. Similarly, there are no trials that demonstrate extended resection is superior to close colonoscopic surveillance after segmental resection. However, there are challenges to a successful postoperative surveillance regimen. Patient compliance, suboptimal bowel preparation, endoscopist skill, and the biology of LS-associated adenomas and cancers ${ }^{30,31}$ all contribute to the development of interval cancers. Interval cancers still develop in 35\% of cases under surveillance ${ }^{32,33}$. Thus, the authors favor extended resection in the medically fit patient.

Obviously, the ultimate decision regarding the extent of resection is determined after consideration of the risks and benefits for each individual patient. Extended resection does result in more frequent bowel movements but also in similar quality of life $\mathrm{e}^{34-36}$. The preoperative discussion should focus on the oncologic benefits and expected bowel function. Patient factors to consider include age, sphincter function, medical comorbidities, willingness to comply with surveillance, and patients' wishes. For example, an elderly patient with multiple comorbidities that may limit life expectancy might be better served by a less extensive segmental resection followed by close surveillance. A similar line of reasoning exists for patients with stage IV disease that requires resection of the primary. In this situation, they are more likely to succumb to metastatic disease rather than a metachronous $\mathrm{CRC}$ and a segmental resection is more prudent.

\section{Chemoprevention}

The routine use of chemopreventive agents for patients with LS remains debated. The Colorectal Adenoma/Carcinoma Prevention Program (CAPP) has been dedicated to studying the chemoprevention of CRC. CAPP-2 is the only randomized placebo-controlled trial for patients with LS. The trial included 937 patients who were randomly assigned to receive resistant starch, $600 \mathrm{mg}$ aspirin, $600 \mathrm{mg}$ aspirin plus resistant starch, or $600 \mathrm{mg}$ aspirin plus placebo ${ }^{37}$. The initial findings did not show any difference in colorectal adenoma or cancer formation up to 4 years. However, analysis at a longer follow up revealed that patients who took aspirin for at least 2 years had a lower incidence of CRC and LS-related cancers than those who took placebo at follow up of nearly 56 months ${ }^{38}$.

It is notable that aspirin is not available in the United States in $600 \mathrm{mg}$ doses. The exact dose, duration of use, and associated side effects need to be further evaluated before recommending routine use in patients with LS. There is an ongoing CAPP-3 trial which will evaluate the effects of three different doses of aspirin $(100 \mathrm{mg}$, $300 \mathrm{mg}$, and $600 \mathrm{mg}$ ) taken for 5 years. The targeted enrollment worldwide is 3,000 patients with LS.

\section{Future directions}

As the basic science of hereditary CRC syndromes continues to be unraveled, the field is rapidly changing. The development of nextgeneration sequencing gene panel testing will improve the ability to diagnose more patients and to define exact mutations. Multiple commercial tests are readily available and their use is increasing. Panel testing should be ordered and interpreted in the context of genetic counseling, as interpretation and appropriate application of the results are critical. The ability to elucidate a precise genetic diagnosis for LS allows a better understanding of its natural history. There are multiple international collaborative groups that are building clinical and genetic databases for patients with LS. Examples include the International Mismatch Repair Consortium and the Colon Cancer Family Registries. Through these collaborative efforts, the nuances between different gene mutations, the relevance of variants of unknown significance, and the spectrum of the syndrome will be better delineated. Furthermore, collaborative groups with their family registries can serve as the foundation for prospective studies to discover more accurate or efficient screening protocols, to study new chemoprevention agents, and to identify non-genetic modifiers that may influence the clinical phenotype.

\section{Competing interests}

The authors declare that they have no competing interests.

\section{Grant information}

The author(s) declared that no grants were involved in supporting this work. 
1. Giardiello FM, Allen Jl, Axilbund JE, et al: Guidelines on genetic evaluation and management of Lynch syndrome: a consensus statement by the US MultiSociety Task Force on colorectal cancer. Gastroenterology. 2014; 147(2): 502-26. PubMed Abstract | Publisher Full Text

2. Dove-Edwin I, Sasieni P, Adams J, et al:: Prevention of colorectal cancer by colonoscopic surveillance in individuals with a family history of colorectal cancer: 16 year, prospective, follow-up study. BMJ. 2005; 331(7524): 1047. PubMed Abstract | Publisher Full Text | Free Full Text

3. Niessen RC, Hofstra RM, Westers $\mathrm{H}$, et al.: Germline hypermethylation of MLH1 and EPCAM deletions are a frequent cause of Lynch syndrome. Genes Chromosomes Cancer. 2009; 48(8): 737-44.

PubMed Abstract | Publisher Full Text

4. F Ward RL, Dobbins T, Lindor NM, et al:: Identification of constitutional MLH1 epimutations and promoter variants in colorectal cancer patients from the Colon Cancer Family Registry. Genet Med. 2013; 15(1): 25-35. PubMed Abstract | Publisher Full Text | Free Full Text | F1000 Recommendation

5. Möslein G, Nelson H, Thibodeau S, et al.: [Rectal carcinomas in HNPCC]. Langenbecks Arch Chir Suppl Kongressbd. 1998; 115: 1467-9. PubMed Abstract | Publisher Full Text

6. Kalady MF, Heald B: Diagnostic Approach to Hereditary Colorectal Cance Syndromes. Clin Colon Rectal Surg. 2015; 28(4): 205-14. PubMed Abstract | Publisher Full Text | Free Full Text

7. Lynch HT, Snyder CL, Shaw TG, et al:: Milestones of Lynch syndrome: 18952015. Nat Rev Cancer. 2015; 15(3): 181-94.

PubMed Abstract | Publisher Full Text

8. Moreira L, Balaguer F, Lindor N, et al.: Identification of Lynch syndrome among patients with colorectal cancer. JAMA. 2012; 308(15): 1555-65.

PubMed Abstract | Publisher Full Text | Free Full Text

9. Green RC, Parfrey PS, Woods MO, et al:: Prediction of Lynch syndrome in consecutive patients with colorectal cancer. J Natl Cancer Inst. 2009; 101(5): $331-40$.

PubMed Abstract | Publisher Full Text

10. Kastrinos F, Allen Jl, Stockwell DH, et al.: Development and validation of a colon cancer risk assessment tool for patients undergoing colonoscopy. Am J Gastroenterol. 2009; 104(6): 1508-18.

PubMed Abstract | Publisher Full Text | Free Full Text

11. Monzon JG, Cremin C, Armstrong L, et al:: Validation of predictive models for germline mutations in DNA mismatch repair genes in colorectal cancer. Int $J$ Cancer. 2010; 126(4): 930-9.

PubMed Abstract | Publisher Full Text

12. F Vindigni SM, Kaz AM: Universal Screening of Colorectal Cancers for Lynch Syndrome: Challenges and Opportunities. Dig Dis Sci. 2016; 61(4): 969-76. PubMed Abstract | Publisher Full Text | F1000 Recommendation

13. Evaluation of Genomic Applications in Practice and Prevention (EGAPP) Working Group: Recommendations from the EGAPP Working Group: can UGT1A1 genotyping reduce morbidity and mortality in patients with metastatic colorectal cancer treated with irinotecan? Genet Med. 2009; 11(1): 15-20. PubMed Abstract | Publisher Full Text | Free Full Text

14. Weissman SM, Burt R, Church J, et al:: Identification of individuals at risk for Lynch syndrome using targeted evaluations and genetic testing: National Society of Genetic Counselors and the Collaborative Group of the Americas on Inherited Colorectal Cancer joint practice guideline. J Genet Couns. 2012; 21(4): 484-93.

PubMed Abstract | Publisher Full Text

15. F Provenzale D, Gupta S, Ahnen DJ, et al.: Genetic/Familial High-Risk Assessment: Colorectal Version 1.2016, NCCN Clinical Practice Guidelines in Oncology. J Natl Compr Canc Netw. 2016; 14(8): 1010-30. PubMed Abstract | F1000 Recommendation

16. F Leenen $\mathrm{CH}$, Goverde A, de Bekker-Grob EW, et al:: Cost-effectiveness of routine screening for Lynch syndrome in colorectal cancer patients up to 70 years of age. Genet Med. 2016; 18(10): 966-73. PubMed Abstract | Publisher Full Text | F1000 Recommendation

17. F Ladabaum U, Wang G, Terdiman J, et al:: Strategies to identify the Lynch syndrome among patients with colorectal cancer: a cost-effectiveness analysis. Ann Intern Med. 2011; 155(2): 69-79.

PubMed Abstract | Publisher Full Text | Free Full Text | F1000 Recommendation

18. F Bellcross CA, Bedrosian SR, Daniels E, et al:: Implementing screening for Lynch syndrome among patients with newly diagnosed colorectal cancer: summary of a public health/clinical collaborative meeting. Genet Med. 2012; 14(1): 152-62.

PubMed Abstract | Publisher Full Text | Free Full Text | F1000 Recommendation

19. F Rubenstein JH, Enns R, Heidelbaugh J, et al:: American Gastroenterological Association Institute Guideline on the Diagnosis and Management of Lynch Syndrome. Gastroenterology. 2015; 149(3): 777-82; quiz e16-7. PubMed Abstract | Publisher Full Text | F1000 Recommendation
20. Barrow E, Alduaij W, Robinson L, et al: Colorectal cancer in HNPCC: cumulative lifetime incidence, survival and tumour distribution. A report of 121 families with proven mutations. Clin Genet. 2008; 74(3): 233-42. PubMed Abstract | Publisher Full Text

21. Hendriks YM, Wagner $\mathrm{A}$, Morreau $\mathrm{H}$, et al: Cancer risk in hereditary nonpolyposis colorectal cancer due to $\mathrm{MSH} 6$ mutations: impact on counseling and surveillance. Gastroenterology. 2004; 127(1): 17-25. PubMed Abstract | Publisher Full Text

22. Senter L, Clendenning M, Sotamaa K, et al:: The clinical phenotype of Lynch syndrome due to germ-line PMS2 mutations. Gastroenterology. 2008; 135(2): $419-28$

PubMed Abstract | Publisher Full Text | Free Full Text

23. F Mensenkamp AR, Vogelaar IP, van Zelst-Stams WA, et al: Somatic mutations in $M L H 1$ and $M S H 2$ are a frequent cause of mismatch-repair deficiency in Lynch syndrome-like tumors. Gastroenterology. 2014; 146(3): 643-646.e8. PubMed Abstract | Publisher Full Text | F1000 Recommendation

24. F Carethers JM: Differentiating Lynch-like from Lynch syndrome. Gastroenterology. 2014; 146(3): 602-4.

PubMed Abstract | Publisher Full Text | Free Full Text | F1000 Recommendation

25. F Carethers JM, Stoffel EM: Lynch syndrome and Lynch syndrome mimics: The growing complex landscape of hereditary colon cancer. World $J$ Gastroenterol. 2015; 21(31): 9253-61.

PubMed Abstract | Publisher Full Text | Free Full Text | F1000 Recommendation

26. Kalady MF, Kravochuck SE, Heald B, et al.: Defining the adenoma burden in lynch syndrome. Dis Colon Rectum. 2015; 58(4): 388-92.

PubMed Abstract | Publisher Full Text

27. F Kalady MF, McGannon E, Vogel JD, et al.: Risk of colorectal adenoma and carcinoma after colectomy for colorectal cancer in patients meeting Amsterdam criteria. Ann Surg. 2010; 252(3): 507-11; discussion 511-3. PubMed Abstract | Publisher Full Text | F1000 Recommendation

28. Natarajan N, Watson P, Silva-Lopez E, et al:: Comparison of extended colectomy and limited resection in patients with Lynch syndrome. Dis Colon Rectum. 2010; 53(1): 77-82.

PubMed Abstract | Publisher Full Text

29. F Parry S, Win AK, Parry B, et al.: Metachronous colorectal cancer risk for mismatch repair gene mutation carriers: the advantage of more extensive colon surgery. Gut. 2011; 60(7): 950-7.

PubMed Abstract | Publisher Full Text | Free Full Text | F1000 Recommendation

30. Win AK, Parry S, Parry B, et al.: Risk of metachronous colon cancer following surgery for rectal cancer in mismatch repair gene mutation carriers. Ann Surg Oncol. 2013; 20(6): 1829-36.

PubMed Abstract | Publisher Full Text | Free Full Text

31. Jenkins MA, Dowty JG, Ait Ouakrim D, et al:: Short-term risk of colorectal cancer in individuals with lynch syndrome: a meta-analysis. J Clin Oncol. 2015; 33(4): 326-31.

PubMed Abstract | Publisher Full Text

32. Mecklin JP, Aarnio M, Läärä E, et al:: Development of colorectal tumors in colonoscopic surveillance in Lynch syndrome. Gastroenterology. 2007; 133(4): 1093-8.

PubMed Abstract | Publisher Full Text

33. F Edelstein DL, Axilbund J, Baxter M, et al.: Rapid development of colorectal neoplasia in patients with Lynch syndrome. Clin Gastroenterol Hepatol. 2011; 9(4): 340-3.

PubMed Abstract | Publisher Full Text | Free Full Text | F1000 Recommendation

34. Fazio VW, O'Riordain MG, Lavery IC, et al.: Long-term functional outcome and quality of life after stapled restorative proctocolectomy. Ann Surg. 1999; 230(4): 575-84; discussion 584-6.

PubMed Abstract | Publisher Full Text | Free Full Text

35. Erkek AB, Church JM, Remzi FH: Age-related analysis of functional outcome and quality of life after restorative proctocolectomy and ileal pouch-anal anastomosis for familial adenomatous polyposis. J Gastroenterol Hepatol. 2007; 22(5): 710-4.

PubMed Abstract | Publisher Full Text

36. F Kiran RP, El-Gazzaz G, Remzi FH, et al:: Influence of age at ileoanal pouch creation on long-term changes in functional outcomes. Colorectal Dis. 2011 13(2): 184-90.

PubMed Abstract | Publisher Full Text | F1000 Recommendation

37. Burn J, Bishop DT, Mecklin JP, et al:: Effect of aspirin or resistant starch on colorectal neoplasia in the Lynch syndrome. N Engl J Med. 2008; 359(24): 2567-78. PubMed Abstract | Publisher Full Text

38. F Burn J, Gerdes AM, Macrae F, et al.: Long-term effect of aspirin on cancer risk in carriers of hereditary colorectal cancer: an analysis from the CAPP2 randomised controlled trial. Lancet. 2011; 378(9809): 2081-7. PubMed Abstract | Publisher Full Text | Free Full Text | F1000 Recommendation 


\section{Open Peer Review}

\section{Current Peer Review Status:}

\section{Editorial Note on the Review Process}

Faculty Reviews are review articles written by the prestigious Members of Faculty Opinions. The articles are commissioned and peer reviewed before publication to ensure that the final, published version is comprehensive and accessible. The reviewers who approved the final version are listed with their names and affiliations.

\section{The reviewers who approved this article are:}

\section{Version 1}

\section{Marc S Williams}

Genomic Medicine Institute, Geisinger Health System, Danville, PA, 17822-2620, USA

Competing Interests: No competing interests were disclosed.

\section{William Grady} Cancer Prevention Program, Fred Hutchinson Cancer Research Center, Seattle, WA, 98109, USA

Competing Interests: No competing interests were disclosed.

\section{Randall Brand}

University of Pittsburgh School of Medicine, Pittsburgh, PA, USA

Competing Interests: No competing interests were disclosed.

The benefits of publishing with F1000Research:

- Your article is published within days, with no editorial bias

- You can publish traditional articles, null/negative results, case reports, data notes and more

- The peer review process is transparent and collaborative

- Your article is indexed in PubMed after passing peer review

- Dedicated customer support at every stage

For pre-submission enquiries, contact research@f1000.com 